\title{
NITROFURANTOIN-INDUCED ACUTE LIVER DAMAGE IN PREGNANCY
}

\author{
Alenka AKŠAMIJA ${ }^{1}$, Gordana HORVAT ${ }^{1}$, Dubravko HABEK ${ }^{1}$, Damir ŽALAC ${ }^{1}$, \\ and Eva JENDRIŠ ${ }^{2}$ \\ Department of Obstetrics and Gynaecology, Sveti Duh General Hospital Zagreb ${ }^{1}$, \\ Department of Obstetrics and Gynaecology, Polyclinic Sunce ${ }^{2}$, Zagreb, Croatia
}

Received in April 2009

Accepted in July 2009

\begin{abstract}
This article presents a rare case of acute toxic hepatitis in thirty-one-year old primigravida. In the $36^{\text {th }}$ week of gestation, the patient was introduced nitrofurantoin $100 \mathrm{mg}$ a day due to symptoms of dysuria and enterococcus isolated from urine culture. After induced delivery at term because of hypertension, repeated laboratory findings showed increased aspartate aminotransferase (AST) and alanine aminotransferase (ALT) and negative hepatitis C and B markers. The patient was subicteric at the time. Coagulation and complete blood count values were within the normal range. Nitrofurantoin therapy was discontinued. Abdominal ultrasound was normal with the exception of a slight hepatomegaly without any lesions, focal or diffuse. Given that discontinuation of nitrofurantoin and introduction of methylprednisolon therapy significantly lowered liver enzyme levels, restoring most of them to normal, we concluded that this was probably the case of toxic liver damage caused by nitrofurantoin.
\end{abstract}

KEY WORDS: antibiotic, hepatotoxicity, pregnant woman, therapy

Nitrofurantoin (NF) is a synthetic antibiotic which belongs to the nitrofuran group with nitrofurazon. It inhibits numerous bacterial enzymes involved in DNA and RNA synthesis, as well as carbohydrate metabolism and other metabolic pathways. It is clinically useful against a wide spectrum of gram-positive (Staphylococcus, Streptococcus, Enterococcus) and gram-negative (E. coli, Serratia sp., Enterobacter, Klebsiella and Citrobacter) bacteria. As such, NF is used widely in treatment and prophylaxis of recurrent urinary tract infections in pregnancy and in general gynaecology (1).

Different xenobiotics, including drugs, may cause liver damage that usually resembles either acute hepatitis, cholestatic liver disease or mixed hepatitis and cholestasis. However, drug-induced liver injury can mimic all forms of acute and chronic hepatobiliary diseases (2).
It has become customary to divide liver diseases in pregnancy into those which coincide with pregnancy and chronic liver disease preceding pregnancy. Toxic drug-induced hepatitis in pregnancy belongs to the first category. On the other hand, there are liver changes induced by pregnancy, which disappear after delivery such as hepatocellular damage caused by severe preeclampsia, eclampsia, and/or the HELLP syndrome (from: Hemolysis, Elevated Liver and a Low Platelet).

This article presents a rare case of acute toxic hepatitis in pregnancy. After excluding all other factors, we narrowed its cause down to nitrofurantoin.

\section{Case presentation}

Thirty one-year old primigravida was admitted to the pregnancy ward in the $38^{\text {th }}$ week of gestation for check up and pregnancy termination. Termination 
was indicated due to elevated blood pressure $(140 / 95 \mathrm{~mm} \mathrm{Hg}$ to $160 / 100 \mathrm{~mm} \mathrm{Hg}$ ) without proteinuria or oedema. On admittance, the patient had irregular contractions and was dilated $4 \mathrm{~cm}$ to $5 \mathrm{~cm}$. Ultrasound check up showed foetus presentating head first, with normal biophysical profile, and normal Doppler sonography of the foetal and maternal circulation. Anamnesis showed allergy to penicillin and family history of hypertonia. During the second trimester of pregnancy, the patient was treated with cefalexin $2 \times 1.0 \mathrm{~g}$ due to $E$. coli isolated from urine culture. From the $34^{\text {th }}$ week of gestation onward she was taking atenolol $1 \times 25 \mathrm{mg}$ prescribed by primary care gynaecologist to treat slightly elevated blood pressure. However, blood pressure was never above 150/95 mm Hg. Coagulation, liver function, complete blood count (CBC), electrolytes, creatinine, and blood uric acid were all within normal ranges during pregnancy. Repeated urine culture was sterile as well. In the $36^{\text {th }}$ week of gestation, the patient started to receive daily doses of $1 \times 100 \mathrm{mg}$ of nitrofurantoin (Belupo, Croatia) due to symptoms of dysuria and enterococcus isolated from urine culture. Excipients were as follows: maize starch, talc, magnesium stearate, carmellose sodium, titanium dioxide (E171), tartrazine (E102), indigo carmine (E132), and gelatine. The patient was taking nitrofurantoin for 10 days.
After admittance to the hospital, laboratory tests showed elevated liver enzymes with normal CBC and coagulogram, without haemolysis (Table 1). Also, no jaundice or itching was detected. Because of the elevated blood pressure $(150 / 100 \mathrm{~mm} \mathrm{Hg})$, elevated liver enzymes, 37 weeks of gestation, and favourable genital finding, delivery was induced with amniotomy and oxytocin infusion (Novartis Pharma Stein AG, Switzerland), $5 \mathrm{IU}$ of oxytocin in $500 \mathrm{~mL}$ physiological saline at $30 \mathrm{~mL} \mathrm{~h}^{-1}$. A live, eutrophic male child weighing $2880 \mathrm{~g}$ and $48 \mathrm{~cm}$ long, was delivered with Apgar score 10/10. Manual exploration of the uterus was performed to remove remaining placenta and the patient was intravenously receiving anaesthetics alfentanil (Janssen Pharmaceutica NV, Belgium), $1 \mathrm{x} 1 \mathrm{mg}$ and propofol $1 \%$ (Fresenius Kabi Austria GmbH, Austria), 1x200 mg. The patient received amoxicillin 1x1.2 mg iv, (Pliva Hrvatska, Croatia) as prophylaxis. Repeated laboratory findings the following day showed increased AST and ALT values, negative hepatitis $\mathrm{C}$ and $\mathrm{B}$ markers, and subicterus. NF therapy was discontinued.

Since we identified several signs of liver failure such as permanent elevation of liver enzymes and subicterus, the patient was transferred to the intensive care unit. There she was repeatedly tested for liver enzymes. Coagulation and $\mathrm{CBC}$ were within the

Table 1 Results of blood analysis after patient's admittance to hospital

\begin{tabular}{|c|c|c|c|c|c|c|}
\hline \multirow[t]{3}{*}{ Parameters } & \multicolumn{5}{|c|}{ Days } & \multirow{3}{*}{$\begin{array}{l}\text { Normal } \\
\text { ranges }\end{array}$} \\
\hline & \multicolumn{2}{|c|}{$1^{\text {st }}$} & \multirow{2}{*}{$\begin{array}{c}2^{\text {nd }} \\
7: 00 \mathrm{~h}\end{array}$} & \multirow[t]{2}{*}{$7^{\text {th }}$} & \multirow[t]{2}{*}{$11^{\text {th }}$} & \\
\hline & $17: 00 \mathrm{~h}$ & 21:00 h & & & & \\
\hline platelets $\times 10^{9} / \mathrm{L}^{-1}$ & 209 & 206 & 195 & 352 & & 150 to 350 \\
\hline $\mathrm{D}$-dimer $/ \mu \mathrm{g} \mathrm{L} \mathrm{L}^{-1}$ & 253 & & 313 & 284 & & 50 to 228 \\
\hline $\mathrm{AST} / \mathrm{U} \mathrm{L}^{-1}$ & 420 & 434 & 846 & 73 & 36 & 11 to 38 \\
\hline $\mathrm{ALT} / \mathrm{U} \mathrm{L}^{-1}$ & 861 & 940 & 1425 & 551 & 241 & 12 to 44 \\
\hline $\mathrm{LDH} / \mathrm{U} \mathrm{L}^{-1}$ & & & 665 & 231 & & 0 to 240 \\
\hline gamma-GT / U L L-1 & & & 45 & 57 & & 11 to 53 \\
\hline alkaline phosphatase / U L L-1 & & & 273 & 153 & & 45 to 127 \\
\hline glucose / mmol L-1 & 5.2 & & & & & 3.8 to 6.0 \\
\hline urea / $\mathrm{mmol} \mathrm{L}^{-1}$ & 5.4 & & & & & 3.0 to 8.0 \\
\hline creatinine / $\mu \mathrm{mol} \mathrm{L}-1$ & 87 & & & & & 75 to 125 \\
\hline uric acid / $\mu \mathrm{mol} \mathrm{L}-1$ & 347 & & 423 & 263 & & 140 to 420 \\
\hline total bilirubin / $\mathrm{mmol} \mathrm{L}^{-1}$ & & & 20.8 & 10.4 & & 3.0 to 17.0 \\
\hline direct bilirubin / $\mathrm{mmol} \mathrm{L}^{-1}$ & & & 8.0 & 2.4 & & 0.0 to 3.4 \\
\hline sodium / mmol L-1 & 134 & & & & & 135 to 150 \\
\hline potassium / mmol L-1 & 4.2 & & & & & 3.8 to 5.2 \\
\hline chloride / $\mathrm{mmol} \mathrm{L}^{-1}$ & 103 & & & & & 95 to 105 \\
\hline
\end{tabular}

AST: aspartate aminotranspherase; ALT: alanine aminotranspherase; LDH: lactate dehydrogenase; gamma-GT: gammaglutamyl transpeptidase

Bolded values are out of the normal range 
normal range. Abdominal ultrasound was normal with the exception of a slight hepatomegaly without any lesions, focal or diffuse. Methylprednisolone (Pharmacia Upjohn, USA) therapy, $80 \mathrm{mg}$ per day was introduced with crystalloid, colloid, and $5 \%$ glucose infusions. Given that discontinuation of NF and the above mentioned therapy significantly lowered liver enzyme levels, restoring most of them to normal, we concluded that this was probably the case of toxic liver damage caused by NF. With improved liver function, the patient was transferred back to the obstetrics and gynaecology ward (Table 1).

The course of postpartum period was normal, and the patient was discharged with normal blood pressure. However, a regular check up with a hepatologist was strongly recommended.

\section{DISCUSSION}

Being a member of a nitroaryl drug group, nitrofurantoin is a lipophilic xenobiotic. Consequently, it is readily metabolised by cytochrome $\mathrm{P} 450$ before elimination. One of the enzymes involved in nitroaryl reduction is NADPH-cytochrome P450 reductase localised mainly in the hepatic endoplasmic reticulum. Oxidation and reduction of nitroaryls depend on the NADPH conditions under which this oxidative system catalyses both enzymatic reactions. Therefore, oxidative and reductive pathways may occur as competitive and simultaneous processes, and the toxicity of lipophilic nitroaryls associated with oxidative stress may be a consequence of relative contributions from both metabolic pathways (3).

Nitrofurantoin is effective in eliminating both Gram-negative and Gram-positive pathogens from the urinary tract. Rapid absorption and excretion by kidneys gives NF its therapeutic value as a urinary antibacterial drug. Its half life ranges from $20 \mathrm{~min}$ to $1 \mathrm{~h}$ (3). The risk of adverse reactions to NF increases with age, and is more common in women than in men ( $89 \%$ vs. $11 \%$ ) (4). In patients with normal renal function, systemic accumulation of the drug is scarce. However, patients with creatinine clearance of $35 \mathrm{~mL} \mathrm{~min}^{-1}$ to $40 \mathrm{~mL} \mathrm{~min}$-1 or a clinically significant elevation of serum creatinine should not receive NF (5). For this reason, patients receiving long-term NF therapy are routinely monitored for changes in renal function (6).

NF crosses the placental barrier and can cause haemolytic anaemia of the foetus due to its immature erythrocyte enzyme system (7).
The most common adverse events associated with NF include nausea, headache, and flatulence (4). Although rare, serious adverse events in patients receiving long-term ( $>6$ months), low-dose NF prophylaxis have also been reported. These include chronic pulmonary reactions, hepatic injury, peripheral neuropathy, and hypersensitivity to NF $(4,8-12)$. Here we report the case of acute liver damage caused by administration of NF. Previous studies indicate that hepatotoxicity is the most lethal NF-related adverse reaction (8-12). NF probably produces massive oxidative stress in hepatocytes, due to the nitroreductive metabolism of the drug (13). However, cases have been reported of immunemediated liver injury $(14,15)$. This supported by lupus erythematosus-like presentation, autoantibodies against nuclear antigen and smooth muscle, and by hypergammaglobulinaemia. In general, determining the cause of hepatic toxicity is complex because this requires liver biopsy and drug rechallenge.

Our patient was taking NF for ten days. This may be too short a period for a hepatotoxic reaction to develop. She had normal creatinine clearance; there were no signs of haemolytic anaemia in either the mother or the child, and the mother's liver enzyme levels declined after discontinuation of NF. We can conclude that NF was responsible for acute liver damage either by direct action or as a result of pregnancy-related metabolic changes. Considering the incidence of liver damage in the HELPP syndrome or preeclampsia and/or eclampsia, assessment of the liver function and patient's general condition is strongly recommended before administering NF to pregnant women.

\section{REFERENCES}

1. Guay DR. An update on the role of nitrofurans in the management of urinary tract infections. Drugs 2001;61:35364.

2. Abboud G, Kaplowitz N. Drug-induced liver injury. Drug Saf 2007;30:277-94.

3. Boelsterli UA, Ho HK, Zhou S, Leow KJ. Bioactivation and hepatotoxicitiy of nitroaromatic drugs. Curr Drug Metab 2006;7:715-27.

4. Holmberg L, Boman G, Bottiger LE, Eriksson B, Spross R, Wessling A. Adverse reactions to nitrofurantoin. Analysis of 921 reports. Am J Med 1980;69:733-8.

5. Vrhovac B. Farmakoterapijski priručnik [Manual of Pharmacotherapy, in Croatian], 5th edition. Zagreb: Medicinska naklada; 2007. 
6. Beigel R, Perets R, Mouallem M. Acute kidney injury, hepatitis, and CPK elevation associated with nitrofurantoin therapy. Am J Med Sci 2009;337:132-3.

7. Bruel H, Guillemant V, Saladin-Thiron C, Chabrolle JP, Lahary A, Poinsot J. Anémie hémolytique chez un nouveauné après prise maternelle de nitrofurantoïne en fin de grossesse [Hemolytic anemia in a newborn after maternal treatment with nitrofurantoin at the end of pregnancy, in French]. Arch Pediatr 2000;7:745-7.

8. Heber MF, Roberts JP. Endstage liver disease associated with nitrofurantoin requiring liver transplantation. Ann Pharmacother 1993;27:1193-4.

9. Millson LC, Angus P, Richards M, Jones RM, Ireton J. Hepatitis due to nitrofurantoin. Med J Aust 1992;156:3479.

10. Volbeda F, Jonker AM, Vecht J, Groeneveld PH. Levercirrose door chronisch gebruik van nitrofurantoïne [Liver cirrhosis due to chronic use of nitrofurantoin, in Dutch]. Ned Tijdschr Geneeskd 2004;148:235-8.
11. Dam-Larsen S, Kromann-Andersen H. Nitrofurantoinlevertoksicitet. Tilfaelde indberettet til Bivirkningsnaevnet 1968-1998. [Hepatic toxicity of nitrofurantoin. Cases reported to the Center for Monitoring Adverse Drug Reactions 19681998, in Danish]. Ugeskr Laeger 1999;161:6650-2.

12. Amit G, Cohen P, Ackerman Z. Nitrofurantoin-induced chronic active hepatitis. Isr Med Assoc J 2002;4:184-6.

13. Paterna JC, Boess F, Stäubli A, Boelsterli UA. Antioxidant and cytoprotective properties of D-tagatose in cultured murine hepatocytes. Toxicol Appl Pharmacol 1998;148:11725.

14. Kelly BD, Heneghan MA, Bennani F, Connolly CE, O'Gorman TA. Nitrofurantoin-induced hepatotoxicity mediated by CD8+ T cells. Am J Gastroenterol 1998;93:81921.

15. Paiva LA, Wright PJ, Koff RS. Long-term hepatic memory for hypersensitivity to nitrofurantoin. Am J Gastroenterol 1992;87:891-3 


\section{Sažetak}

\section{AKUTNO OŠTEĆENJE JETRE UZROKOVANO PRIMJENOM NITROFURANTOINA U TRUDNOĆI}

Autori prikazuju rijedak slučaj akutnog oštećenja jetre - akutni toksični hepatitis u 31-godišnje primigravide. U 36. tjednu trudnoće zbog dizuričnih smetnji i dokazanog enterokoka u urinokulturi ordiniran je nitrofurantoin 1x100 mg. Nakon terminski induciranoga poroda zbog hipertenzije, ponovljene laboratorijske pretrage upućuju na značajno povišenje vrijednosti jetrenih enzima uz negativne markere na C i B-hepatitis te subikterus. Koagulogram i crvena krvna slika bili su uredni. Nitrofurantoin se isključuje iz terapije. Abdominalni ultrazvuk upućuje na hepatomegaliju bez fokalnih ili difuznih oštećenja.

Nakon isključenja nitrofurantoina iz terapije uz metilprednizolon, vrijednosti jetrenih enzima se normaliziraju, što potvrđuje slučaj toksičnog oštećenja jetre uzrokovanog nitrofurantoinom.

KLJUČNE RIJEČI: antibiotik, gravidne žene, hepatotoksičnost, terapija

\section{CORRESPONDING AUTHOR:}

Dubravko Habek, MD, PhD

Department of Obstetrics and Gynaecology, General Hospital Sveti Duh Sveti Duh 64, HR-10000 Zagreb, Croatia

E-mail:dubravko.habek@os.t-com.hr 